\title{
Being young in Africa: the politics of despair and renewal
}

Abbink, G.J.

\section{Citation}

Abbink, G. J. (2005). Being young in Africa: the politics of despair and renewal. In African dynamics (pp. 1-33). Leiden ;

Boston: Brill. Retrieved from https://hdl.handle.net/1887/9608

Version: $\quad$ Not Applicable (or Unknown)

License: $\quad$ Leiden University Non-exclusive license

Downloaded from: https://hdl.handle.net/1887/9608

Note: To cite this publication please use the final published version (if applicable). 


\section{Being young in Africa: The politics of despair and renewal}

\section{Jon Abbink}

The 'problem of youth' in Africa

In his most recent book on Africa, Négrologie, the French author Stephen Smith makes a sober assessment of Africa's problems: 'il faut cesser de travestir les réalités de l'Afrique en mêlant ce qui serait souhaitable à ce qui existe .... le présent n'a pas d'avenir sur le continent' (2003: Avant Propos). Even if we are less Afro-pessimist than Smith, see more diversity and variety than he does and look for positive aspects, this remark could very well apply to the overal situation of young people in Africa. They are facing tremendous odds and do not seem to have the future in their own hands. While there has been progress in some respects - for example, in education, migration and job opportunities in the urban arena - the exponential population increase and the fierce competition for resources within the contexts of malfunctioning or failing states have led to a relative decline in the well-being and social advancement of young people in Africa. They are growing up in conditions of mass unemployment and are facing exclusion, health problems,' crisis within the family due to poverty and the AIDS pandemic, and a lack of education and skills. They also are marginalized in national state policies and have a weak legal position. African youths are over-represented in armed rebel or insurgent movements of various kinds as well as in criminal activities, to which they ate so easily recruited. There is no prospect that this situation will change for the better in the near future.

1 This starts early. According to Black, Morris \& Bryce (2003: 2226), there was a child mortality rate in 2000 of 176 per 1000 live births in Sub-Saharan Africa (as against 6 per 1000 in developed industrialized countries) 
This introduction treats a few key aspects of the question of youth in Africa and is not exhaustive. For instance, little will be said about evidently important subjects such as young refugees, migration and its impact on youth, the culture of street children or the role of youth in the labour force and in labour movements.

It is a paradox that while children in Africa are highly valued by adults, the ability, and perhaps even the interest, to care for them declines as they become adolescents. Poverty and destitution, violence, migration, AIDS, and the breakdown of the family also contribute to this. The simple fact is that most of Africa's young people are no longer growing up in the relatively well-integrated societies described in rich detail by anthropologists and historians only one or two generations ago: monographs on, for example, the Nuer, the Dinka, the Murle, the Tiv, the Meru, the Kpelle, the Somali, the Acholi, the Kikuyu or the Karimojong give the impression of another world. Only faint traces of social order and cultural integrity still exist. Most of these societies have transformed into impoverished and internally divided wholes, with many of them caught up in violent conflict and marginalization. Even the last bastion of African society

- the (extended) family - seems to have succumbed to the pressure as parents and relatives find it increasingly difficult to foster the young and provide them with a relatively carefree period in which to grow and develop. This transformation has led to a large proportion of youth having no well-defined place in society and being vulnerable and dependent, especially in urban conditions. McIntyre et al. (2002: 8) have mentioned the lack of 'constructive social incentives' in society as a key feature that narrows youngsters' possibilities for more or less orderly growth and development, and makes them look elsewhere for survival and opportunities.

The dilemma is how to write about youth in Africa without falling back on the bleak picture of crisis, crime and violence that the available statistics and research reports seem to confirm time and again. And how can one do justice to the many positive exceptions and to the versatility and survival skills of youngsters in such dire straits? $?^{2}$ It would be a mistake to deny African youth intentionality of action and agency, as has so often happened in Africanist discourse.

While not denying the disturbing facts, it has to be noted that perceptions play an important role. Being young in Africa is widely and consistently perceived as problematic in essence. Social analysts, policy makers, NGOs, 2 See Falola (2004). For a moving example, see also Sili, the heroic girl who sells
newspapers, in the film La Petite Vendeuse du Soleil by Djibril D. Mambéty (Senegal 1998). governments and international organizations all reiterate that African youth is in deep trouble and enmeshed in violence. While understandable, this view is overburdening and prejudges the issues before understanding them. The assumption that developed Western or other modern industrialized societies can be held up as the example must also be rejected. Both theoretically and empirically one needs to avoid positing 'youth' and generational tension in Africa as an inherently destructive or exceptional factor in the social order. This reveals a kind of Hobbesian worldview applied to Africa. On the contrary, there is a need to integrate the youth factor as a necessary element in any social analysis of African societies, thus testing the relative autonomy of youths as actors (re)shaping social relations and power formations. We also need to keep a comparative perspective and recognize that not only youth in Africa face challenges but equally those in many countries in the Middle East, ${ }^{3}$ South America, Asia and the developed 'North'.

This book chiefly addresses the political and conflict-generating 'potential' of youth and generational conflict in Africa and describes their societal manifestations and causes. It is now evident that the chronic problems faced by youth - and their responses to them - have clear political implications. By their sheer numbers, their availability, and their eagerness to take up anything that may relieve them of conditions of poverty, idleness or ennui, youth are easily recruited by political parties, armed groups or criminal networks. In addition, youths pose their own demands and form their own movements. Here the perception that they are all engaged in socially undesirable or criminal activities, or are unemployable (youth as lumpen, as a lost generation, etc.) is erroneous, as the many developments in African popular culture (music, theatre, fashion), religious revival, new indigenous NGOs, the creative appropriation of ICT in Africa, and of course sports make clear: youths are active on all fronts (see Trudell et al. 2002). In this, their direct or indirect political role is evident.

The concept of 'generation' is arguably a difficult one, and perhaps not explanatory as such. But apart from recognizing a psycho-biological factor youths in adolescence want to act, to test the world they are engaging, and do not shun aggression against rivals or those above them ${ }^{4}$ - young people and rebellious groups in Africa consistently phrase many of their problems in terms of generational opposition. They often say that they receive too little attention from those in power - both in rural society (chiefs, ruling age grades) and in the cities (political leaders, party bosses, teachers, etc.). We thus take our cue from

3 See the UNDP's 'Arab Human Development Reports' of 2002 and 2003 , at: www. undp.org/rbas/ahdr/ahdr1/presskit1/PRExecSummary.pdf and www.undp.org/rbas/ahdr ahdr2/presskit/6_AHDR03ExSum_E.pdf.

${ }^{4}$ Cf. Daly \& Wilson's study (1993) on the 'young male syndrome'. 
this and use 'generation' as a heuristic concept but recognize its connection with other inequalities like class, ethnicity or religious denomination.

Generally speaking, generational tension and change occur anywhere, and are always 'problematic'. The phenomenon is multidimensional (social, psychological and political) and is as old as human society. It is a universal and popular theme reflected in the literary imagination from across the world: the Oedipus myth, Old Testament stories, tribal myths, and great novels like Turgenev's Fathers and Children (1862), Stendhal's Vie de Henri Brulard (1835), Salinger's The Catcher in the Rye (1951) or Ellison's The Invisible Man (1952). ${ }^{5}$ Sigmund Freud made the theme a cornerstone of his psycho-analytic theory and elaborated it in Totem und Tabu, a 1913 monograph on cultural history describing the archetypal rivalry between the generations. ${ }^{6}$ But the ways in which social systems have dealt with this demographic-biological fact of age and generational difference varies widely. In most modernized industrial societies, generations are informally delineated, boundaries between 'young" and 'old' are fuzzy, and the category 'young' often acquires a curious prestige and aura of desirability not based on social merit or particular achievements, the latter no doubt connected to the new consumer value of youth for commercial companies. Hence, contestation and struggle as to boundaries, symbolism, prestige and power in the public domain of contemporary societies are common.

In Africa, a large number of agro-pastoral societies still have intricate age systems, where the generational problem is formally 'solved' with the assigning of social roles to age groups and maintaining clear ritual boundaries between them, access to which can only be gained by ritual transition and formal confirmation. ${ }^{7}$ Sometimes the application of this age principle has led to an ageset system, with fixed, mutually exclusive categories of people of a certain age that are cohesive and move through time as a collective, or to generation sets with alternating ranked categories where parents and children are always members of different opposed groups and have ritual obligations towards each other. They are set in a hierarchical order, each having an expected code of behaviour and a circumscribed public role. Good examples are the gaada systems of the Konso, Burji and various Oromo peoples (Guji and Boran) in

5 The Ethiopian masterpiece Frgir iske Meqabir ('Love until the Grave') by Haddis Alemayehu published in 1973 is an African example that describes the gradual emergence of disenchantment and rebellion among Ethiopia's young generation. It was in many ways a prophetic novel: one year later the Ethiopian revolution began.

6 For some recent views on children and youth in African fiction, see the special issue of Mots Pluriels at: www.arts.uwa.edu.au/MotsPluriels/MP2202index.html.

7 For a classic, formal analysis of the complexities of age systems, see the study by Stewart (1976). For Africa, see Abélès \& Collard (1985). southern Ethiopia (cf. Aguilar 1998, Bassi 1996, Hinnant 1978), the Nyangatom generation system (Tornay 2001), or the age organization of the Kenyan Gusii and Meru (Péatrik 1993, 2003), all of a fascinating ethnographic complexity. While the actual transitions were often marked by rituals and by symbolic resistance or violence, no one fell outside the system and all acquired a clear and recognized social identity. The drawbacks of these systems are that the gerontocratic element is too strong and that they are not always capable of dealing with external changes and shocks (see Simonse this volume) ${ }^{8}$ Other types of social organization in Africa are still strongly informed by lineage and clan principles, with youths expected to defer to elders and lineage seniors. While in the post-colonial era these inherited principles of social order are more respected in the breach than in the keeping, many of the underlying ideas of reciprocity, complementarity and mutual obligation (for example via kinship relations) are still present. There is a pattern of moral expectation that many youths in Africa feel is being flouted by the older generation. Religious notions to which they appeal reinforce this. These are ingredients for the emerging struggles between the 'older' and the 'younger' generations in Africa. In explaining the youth experience in Africa, a processual view on the place and role of youth is needed to take into account both these struggles as well as the existing cultural representations on and of youth, recognizing that they are set in a context of faulty modernization, social rupture and inequalities of economic opportunity or power.

\section{Defining 'youth'}

Implicit in the above is that we know what we are talking about when using the terms 'youth' and 'youngsters'. When is one young in Africa? Certainly below the age of 14, the largest age group in Africa. But what about people in their thirties or early forties? Several authors include groups, advanced in biological age, in their definition of youth. Obviously, 'youth' is partly a socially constructed or constituted category, like most social phenomena. Some people who are well into their thirties have not completed their education, have no job, are

${ }^{8}$ This was also demonstrated by Eisei Kurimoto in his conference presentation entitled 'War, Displacement and an Emerging New Generation: Pari Youths in South Sudan and Beyond' at the African Studies Centre, Leiden, 24 April 2003. He mentioned that during the upheaval of Päri society during the Southern Sudanese civil war, the age system was destroyed, with youngsters even shooting the members of the incumbent ruling grade, the mojomiji. Interestingly, however, the age system was reinstated in exile, although in a different form. 
not in a position to raise a family, etc. indeed sociologically resemble the biologically younger people with whom they share a way of life defined by poverty and deprivation. In Africa there are many such people who have had to delay their entry into adulthood: they feel excluded and powerless, and struggle to survive. But despite this there has to be a limit to calling someone a 'youngster': forty-year olds, for instance, are no longer youths but pass into another category, perhaps that of street people, beggars or vagrants. For this tragic category of people, the adage of 'youth possessing the future' or 'having a whole life before them' is vacuous: they are, by local standards, already middle-aged and have effectively lost the promise of youth. No strict definition of age limits can be given (see also d'Almeida-Topor 1992). For the above reasons and following statistical custom, we pragmatically limit the category of 'youth' in Africa to the 14-35 age bracket. ${ }^{9}$ Under 14, they are children, usually dependent on older people and not accepted as adults, while over thirty-five they are, or were, more or less expected to be socially independent, have a family and have acquired some social status of their own. ${ }^{10}$ Finally, youth comprises males and females. The gender dimension, however, is often relegated to second place in studies and policies about youth in Africa. It may be true that young males are dominant in politics, on the street, in the job market, in insurgent movements and as perpetrators of crime and violence, but the same social problems are equally faced by females. Conflict and violence have a particularly dramatic impact on the perception and construction of gender relations, with new, more aggressive formations of masculinity - within already existing patriarchal relations - often leading to more dependency, abuse and subordination of girls and women (see Jok, this volume). The gender perspective is not yet sufficiently integrated in youth studies.

\section{Recent debates}

In the post-colonial nation-states of Africa that emerged in the early $1960 \mathrm{~s}$ generational tension has become a recurrent feature of politics. This has been

9 Thirty-five is too high for the customary census bureau practices, but in view of conditions in Africa can be defended. The US Population Reference Bureau (see: www.prb.org) takes as the category 'youth' the ten to twenty-four age group. The under-10 group are children. Another commonly used bracket is 14-25.

10 As a result of the AIDS catastrophe in Africa, many orphaned children under 14 are already the main breadwinners for their younger siblings, effectively running the family. This illustrates the need to take the age boundaries as loose, open borders for the category 'youth'. fuelled by the young generation that has grown up since independence, who both as an age group and as a socially blocked generation of sons and daughters of the independence or uhuru generation, has fared rather badly. In the early years after independence, many young and promising politicians, like Tom Mboya in Kenya, had to be contained by the 'elders' and were manoeuvred out, or eliminated. Forty years of post-colonial history has not shown a takeover of power by the young or a substantial improvement in the life of youth in Africa in general. ${ }^{11}$ To be young in Africa came to mean being disadvantaged, vulnerable and marginal in the political and economic sense. A long historical process, shaped by authoritarian colonialism, post-colonial state failure and a generally problematic engagement with material modernity has yielded the conditions of crisis and upheaval under which youths in Africa are growing up. State failure and the peculiar nature of the African bureaucratic bourgeoisie that are living on 'rent-seeking' not productive investment, dubious Cold War alliances, and a lack of economic initiatives have played their role. But in a wider sense, even before independence, much of the traditional social fabric and cultural meaning had been lost, and the socialization of the young and the transmission of social capital or indigenous skills and knowledge were interrupted. ${ }^{12}$ Education and employment did not offer alternative routes, or only for a select few. One might metaphorically say that, in a way, the socially and culturally accepted initiation of the young into adult society - that in many societies used to be ritually marked by rites of transition and a period of seclusion and training - can no longer be properly accomplished in Africa. This metaphor is apt because youth interpret their problems through a moral prism: they often suggest that adults have given up on them or have reneged on their social and moral obligations towards them. There is also a psychology of humiliation and shame involved.

Globalization and hegemonistic processes emanating from the contemporary world system are now also affecting African societies - politically and economically but also socially and culturally. The continent's assets (minerals, raw materials, wildlife, art objects, etc.) are being siphoned off in a predatory and uncontrolled manner, its productive capacity stunted and caught in relations of persistent inequality in a resurrected laissez-faire style of capitalism, ${ }^{13}$ and

$"$ A pioneering collection surveying many of the conditions of youth in Africa was d'Almeida-Topor et al. (1992).

d'Almeida-Topor et al. (1992).

12 The famous novel Things Fall Apart by the Nigerian author Chinua Achebe (1958), was a prophetic view of things to come.

${ }^{13}$ The World Bank and especially the IMF have a poor record of success in Africa over the past 20 years. Structural Adjustment Programmes have only rarely achieved anything durable, as they were often based on wrong premises and short-term perspectives. 
African norms and values are being declared irrelevant or harmful, in line with a long tradition of alienating discourse on Africa by both the Islamic and the Western world. These processes are often actively supported by the African political elites in place. While globalization and social change offer new opportunities, most of the scientific as well as policy discourse on the subject is preoccupied with crisis-related aspects, fuelled by recent hotly debated issues such as child soldiers (Machel 1996, Stohl 2002, McIntyre et al. 2002, Peters \& Richards 1998), ${ }^{14}$ AIDS orphans (Dane \& Levine 1994), ${ }^{15}$ child slavery and trafficking (Rossi 2003), ${ }^{16}$ female genital mutilation (Gosselin 2000) and the sexual abuse of young children, especially in Southern Africa (Richter, Dawes \& Higson-Smith 2004). Recent studies reiterate the fact that the social insertion of the young, i.e. their more-or-less stable and predictable inclusion and incorporation in the wider society during adolescence, is highly precarious.

A number of responses in the academic literature arise from this picture of despair and doom. One is the 'agency' response that emphasizes the active role of youth in finding their own answers to the problems they face, and thus having them shape their own destiny. They are versatile, resilient and make do with whatever they can to survive. They often move into alternative modes of expression but can influence policy and local society. The annual 'Day of the African Child' (16 June) commemorates the 1976 Soweto youth revolt on that day, a prime example of a mass youth protest that made a difference. ${ }^{17}$ Another telling example of the leverage that youth can have and consciously use is given in Lesley Sharp's study (2002) of Malagasy youth identity politics, historical memory and political change. Her analysis demonstrates that youth, as an intermediate social category, can catalyze processes of change in the wider society. In South Africa, youth was at the forefront of the broad social movement that mobilized anti-apartheid protest and resistance in the $1980 \mathrm{~s}$, thus

The ideal of trimming down the oversized African state and its huge budget deficits was achieved only at a very high social cost. For a recent critique, see Schatz (2002), also Van de Walle et al. (2003).

${ }^{14}$ See also a special website on the subject:

Www.essex.ac.uk/armedcon/themes/child_soldiers/default.htm.

${ }^{15}$ See the BBC news item 'AIDS Orphans to Double', at: http://news.bbc.co.uk/1/ hi/health/2120449.stm and the article "Tidal Wave" of AIDS orphans rising', New Scientist, 13 July 2004, at: www.newscientist.com/news/news.jsp?id=ns99996143. At present there are an estimated 11 million AIDS orphans in Africa: one child in every 20. See: http://www.oneliferevolution.org/unbelievable/.

${ }^{16}$ See this alarming UNESCO report at:

www.unicef-icdc.org/publications/pdf/insight9e.pdf.

${ }^{17}$ See Smith (2003: 67-68). laying the foundations for a democratic transition in the 1990s (see Van Kessel 2000).

Part of the agency perspective is to recognize that youth has been equally inclined, especially over the past few decades of social decline, to be actively involved in crime and predatory armed movements. ${ }^{18}$ This is often explained by their tangible despair, their search for role models (among males) and a lack of other options (see below). It is well-known that youths are the driving forces in numerous rebel or guerrilla movements (see Young 1997 on the Ethiopian TPLF) and neo-traditional protest movements (see Kanneworff 2004 on the Mungiki and Kagwanja this volume), sometimes with a major socio-political impact. The agency approach is usually accompanied by a call to take the study of youth, in Africa and elsewhere, more seriously and to listen to young people's voices. Agency, both on empirical and epistemological grounds, should not - and cannot - be denied. As a meta-concept it is useful to sensitize us to the fact that social structure is an interactive whole where the actions of individuals and minor groups play a role and 'realize' as well as transform structures. Youths are neither universally manipulated nor passive actors in a world designed by others but individuals who are trying to chart their own course. The dynamics of collective movements is incomplete without a realist perspective on individual agency and emergent forms of action. Various chapters in this book provide clear evidence of this (Dorman, Burgess, Marguerat).

A second response is the interventionist one that is based on the premise that, in the face of enduring youth deprivation, remedial policies should be developed and implemented, and that both local and international NGOs should be actively involved in creating programmes and policies designed to help youngsters attain independence, employment, civic representation and social standing. Target groups are often street children, young ex-combatants and chronically unemployed and unskilled youths. On the basis of well-described case studies, ${ }^{19}$ national governments are being urged to more actively 'invest in people ${ }^{20}$ and develop education and employment policies that assist youngsters, at the peril of losing them and pushing them into socially subversive activities

${ }^{18}$ Compare the various armed groups in the Liberia and Sierra Leone wars, clan-based militias in Somalià, the armed groups in the Democratic Republic of the Congo, the young thug squads organized by Zimbabwe's current government, Nigerian vigilante groups, youth recruitment into the Sudanese state army and rebel movements, and the devastation by the Lord's Resistance Army in northern Uganda.

19 For one comprehensive collection of studies on Ethiopia, see Habtamu (1996).

${ }^{20}$ See Chapter 4 in the World Bank document Can Africa Claim the 21st Century?

(Washington, DC, 2000). 
or political protest. Even a well-controlled new state like Eritrea, which could count on a high level of commitment from youth in its war of independence against the Ethiopian regime, is faced with youth disenchantment, as Dorman's chapter shows.

Both these responses are closely connected to the 'rights discourse' (see De Waal \& Argenti 2002), which develops a normative approach towards youth and its rightful place in society. No one will argue the value of realizing rights and the increased empowerment of children and youth, but apart from the need to define or understand what these rights are or have to be in specific contexts, current conditions in Africa are unfavourable for attaining this goal in the foreseeable future.

A third response is the more descriptive-analytic one, trying to offer historically and sociologically grounded accounts to explain what has been happening with African youth in the past century and to lay out current scenarios. Agency rightfully calls attention to the individual power of actors and their cumulative impact, clarifying what the structural constraints of social and political conditions are on individual behaviour. The actor-oriented perspective associated with the agency approach is productive but only when the interaction with structural elements is taken seriously. The interventionist approach has a laudable ethical dimension and assumes the self-evidence of rights. Rights, however, are the issue of negotiation and political struggle, and cultura perceptions about them differ notably across communities. An analytic perspective, informed by a realist theory of social action that focuses on generative structures explaining social phenomena has a particular interest in the interaction of structure, agency and normative or reflexive discourse. Needless to say, therefore, the three approaches are interrelated but an analytic approach seems necessary for initial understanding. In this book, a mix of approaches is found but the analytic one predominates.

The aim of this collection is thus to present, through a variety of cases, a comprehensive overview of all crucial socio-cultural and historical factors involved in the youth experience in contemporary Africa. There is a predictable diversity in theme and approach but all contributions are based on original fieldwork and attempt to address conflict-generating processes, test hypotheses on generational tensions, and assess the political impact of youth problems in society. They intend to provide more general insights that could be taken up by politicians at government level, NGOs and international (donor) organizations. Most of the contributors to this book are historians, sociologists and anthropologists. Some have, on the basis of their scientific work, played a pioneering role in action-oriented research and project implementation in the field of youth problems in Africa (see the chapters by Simonse, McIntyre, Peters and, especially, Marguerat).
Youth and generational tensions then and now

An historical-anthropological analysis of youth and age in Africa reveals that generational conflict, as a socio-cultural phenomenon, has existed for a long time. But due to rapid processes of change related to colonialism, modernization, social upheaval and disturbed demographic trends such as runaway population growth, ${ }^{21}$ this phenomenon has assumed crisis proportions, fundamentally different from those in the past. Virtually everywhere on the continent, youth, while forming a numerical majority, ${ }^{22}$ are in a situation of dependency, economically marginalized, and feel excluded from formal power and prestige, even when the time has come for them to become part of established society. The dominant power structures and patronage networks are rigid, conservative and often vertically organized with reference to ethnic or religions groups. These function as frameworks of 'extended kinship' or moral community with limited access. In the absence of judicial or state structures guaranteeing some kind of equity or redistribution effect, patronage and power have a tendency to exclude non-insiders. This makes for a politically volatile situation in many African countries (Cruise O'Brien 1996). The sheer numbers involved make it acute as young people form the large majority and exert pressure due to the size of their group. This unprecedented demographic imbalance therefore has a political dynamic of its own.

African societies and politics could be reconsidered in the light of these generational tensions engendered by dramatic population growth in conditions of state stagnation or failure. Inequality and dependency seem to have marked the generational relations in pre-colonial and rural African societies as well, but there may be essential differences in the social organization of inequality and age organization, as well as in their valuation in past and present societies. In

\footnotetext{
21. Many pre-colonial African societies had certain mechanisms, for example regulatmg marriage age and birth frequency, that kept population growth in check and in line with economic possibilities. See Legesse (1989) for the example of the traditional Boran system. Today, no African society has yet entered the stage of demographic transition (towards lower fertility and higher life expectancy). The average figure for population growth in Africa is $2.7 \%$, four times the average of industrialized countries. A similar fast growth, though, is seen in some other parts of the world, for example the Middle fast East.

${ }_{22}$ Youth between ages 0 and 24 in Africa make up a substantral majority; those under age 15 already constitute some $45 \%$ of the total Sub-Saharan African population (1999 UNDP figures). According to the US Population Resources Bureau, in 2003 youth between 5 and 24 made up $47 \%$ of the total Sub-Saharan African population (See: www.prb.org/template.cfm?template=InterestDisplay.cfm\&InterestCategoryID=210). In Western industrial societies, the population under the age of 15 is less than $20 \%$.
} 
many rural, especially pastoral, societies of today, for example in East Africa, this problem can be observed at first hand because seemingly well-integrated age organization societies, where social relations are largely based on a metaphoric use of 'age' as a social distinction and power marker (cf. Turton 1995: 100), have great difficulty in absorbing the challenges and problems of 'modernity'. They are faced with processes of economic exclusion, unmediated commercialization, wrong-headed state policies and so-called development schemes (Fratkin 1998) that do not enhance interaction, cooperation or wellbeing, but rather the reverse. These societies also face intensified armed conflict, or its members see short-term advantages in resorting to it. The wide availability of arms (particularly automatic rifles) has enhanced this. One could think here of societies like the Karimojong (Dyson-Hudson 1966, see also Simonse this volume), the Nuer (Hutchinson 1996), the Suri (Abbink 1994, 2003,2004 ), the Nyangatom (Tornay 2001) or the Päri (Kurimoto). ${ }^{23}$

These generational tensions in the post-colonial age of modernization or, in a wider sense, modernity - as a comprehensive socio-cultural, not only politicaleconomic, phenomenon - have led to the massive recruitment and involvement of youths in revolutionary or insurgent movements, starting in the 1970s. The guerrilla movements in Ethiopia - the Eritrean People's Liberation Front (EPLF) and the Tigray People's Liberation Movement (TPLF) - were clear examples of this, but also the armed movements in Angola, Mozambique, Sierra Leone and Liberia. Youths, mostly males, with no educational or career options in an impoverished or marginalized society see here the opportunity to join an exciting movement in which they are valued as members and fighters, and where there is promise of social change, justice or, at best, loot. While many of these earlier movements (such as the EPLF, TPLF, PAIGC in Guinea-Bissau, NRM in Uganda) had social-revolutionary programmes and partly realized them, in the early $21^{\text {st }}$ century the ideological content of armed insurgent movements is often lost (cf. Mkandawire 2002). As is most evident in Somalia, Congo-Brazzaville (in the 1990s) or in the Democratic Republic of the Congo, many seem to have turned into predatory looting machines that seek not only material booty and destruction but also humiliation though torture and mutilation, terror through the arbitrary killing of innocent individuals, and sexual gratification, as is evident from the large-scale abuse of women and girls in the civilian population. In a mimetic circle of violence and intimidation, national army troops sent to combat insurgents, and often also including child

\footnotetext{
${ }^{23}$ Kurimoto, 'War, Displacement and an Emerging New Generation', see note 8.
}

soldiers, come to join in such practices. ${ }^{24}$ The remsertion of such combatants in any kind of normal society is fraught with problems (see Peters this volume).

\section{Youth and politics}

When looking more closely at African politics in the post-colonial era, one notes that they were marked by immobility and the monopolizing behaviour of the elites in power, sustained by often surrealistic and ruthless methods of intimidation. In much of Eastern and Southern Africa, the generation that secured independence blocked the path of the younger generation in political life and in the state bureaucracy. ${ }^{25}$ Robert Mugabe's pathetic and destructive policies in Zimbabwe in the last few years illustrate this graphically. Namibia is another example: incumbent President Sam Nujoma prepared constitutional changes in 1999 that allowed him to extend his increasingly autocratic presidential rule for a third term. Eritrea may be another, as the current president has eliminated any opposition, delayed party formation and elections indefinitely, and insulted or imprisoned youths who contest certain national policies. Power is seen as indivisible and thus the old idea of the prerogative of the senior generation (having 'led the struggle' for independence or freedom) has come full circle.

In the first decades of African independence, young leaders were carefully screened and contained. They were enticed to enter the ranks of the reigning elite, to set themselves against each other, or were banned. As the years went by and the older generations clung on to power, youths became prominently involved in opposition politics, provided they were not co-opted or neutralized by being offered positions in the existing system. Not only were they present in opposition factions within the reigning political parties (often the only ones allowed), they were also involved in the potentially powerful labour unions and in student movements. In addition, they set up or joined armed insurgent

24 The scale and cruelty of such destruction and abuse in Africa - the latest case (2003. 2004 ) being the mass killings, "ethnic cleansing" and scorched-earth campaigns of Sudan's government and it allied militias in Darfur - is often beyond belief.

${ }_{25}$ Witness Kenya, where Mwai Kibaki, a coeval and advisor of the country's first president, Jomo Kenyatta, in the early years of independence, was elected president in the 2002 national elections at the age of 71 . His participation in politics, as well as that of anyone else over the age of fifty, was heavily criticized by the Mungiki youth movement, which called for a shake-up and generational change in Kenyan politics. Interestingly, as Kanneworff (2004: 88) notes, Mungiki youngsters' ideas here referred back to notions of the Kikuyu age-grade system. 
movements in the 1970s and 1980s, some of which ultimately successfully took over power (cf. Clapham 1998).

Youth was also at the forefront of democratic agitation in Africa in the late 1980 s and 1990 s but their success was limited, except in the case of South Africa. The prospects of democratization and socio-economic development that seemed to open up after 1989, the year of the fall of Communist regimes in Eastern Europe and the end of the Cold War, were not realized. New approaches proposed by the World Bank ${ }^{26}$ and other international institutions and donors led to economic liberalization and regime pressure in many countries, but these were not sustainable. They were often accompanied by new informal power configurations and criminalized elite activities. Established systems of patronage, endangered by new but often inconsistent demands for 'good governance' and political accountability by donor countries and international organizations, were redefined, allowing many old-style elites (as well as new ones) to reinstate or reshape neo-patrimonial rule. The average citizen, let alone the younger generation, in Africa did not substantially benefit from reforms. In an important and widely read study, Paul Richards (1996) has interpreted the violence in Sierra Leone as issuing from a wider crisis affecting youth in a declining patrimonial state that could not cater to its young population. The country's forest resources, in high demand on the world market, became an issue of competition and violence between state and rebels, and allowed marginalized youth to carve out a domain of alternative careers and self-assertion in line with traditional cultural notions as well new social values acquired in the setting of struggle. No 'natural inclination' of youth to behave violently can explain their presence in socially destructive movements. The breakdown of a socio-political and moral order in the wider society and the degree of governability of a certain type of state are more likely to precipitate this.

In the wake of political and economic changes in the early 1990s and the failure of effective regime changes toward democracy and equity, new armed conflicts have proliferated across Africa, with youth playing a prominent role in them. The part played by university students in ideological contestation (see Arnaut and Konings in this volume) in the absence of strong civil-society organizations, like labour unions, parties, religious groups or local NGOs, is remarkable. A good early example is Imperial Ethiopia, where the students created a new leftist discourse of change and social reordering that had a huge influence on the army officers who took over power in 1974 (cf. Balsvik 1985). Students in Ethiopia have remained active to this day. Another is Madagascar,

\footnotetext{
${ }^{26}$ See Africa: from Crisis to Sustainable Growth (1989).
}

where student uprisings have led to the fall of two governments (Sharp 2002: 10). In the past few decades, Africa has also seen the emergence of relatively powerful student movements in countries like Cameroon, Côte d'Ivoire and Mali. Many insurgent and guerrilla leaders have risen from the ranks of the students, often, as in the case of Ethiopia, steeped in a Socialist/Marxist ideology.

Throughout the post-colonial period, regimes in power have often created youth wings of the ruling party that were not loathe to exercise intimidating violence on opponents (as in Kenya, Cameroon, Malawi and most recently in Mugabe's Zimbabwe). So-called political action here has gradually turned into criminal violence, which shows that young people can easily be manipulated into such movements directed by adult power-holders. The PRESBY group mentioned in Piet Konings's chapter (this volume) is but one example of a violent, unabashedly pro-government militia formed to build a counterweight to democratic and grassroots Anglophone protests against social injustice and political manipulation by the Cameroon elite. The rapid dismantling of Zimbabwe in recent years is a contemporary example that demonstrates how the manipulation of youth into semi-criminal, pro-regime militias can be observed as it happens (Ndlovu 2003). Often, as in northern Nigeria, there is a relationship between youth action and its use for political purposes. No doubt the controversial introduction of Islamic shari'a as state law in many northern Nigerian states (which goes against the federal constitution) partly reflects the wish of local people to have speedy and predictable justice in conditions of rising crime, but it also supports the political agenda of elite leaders who have lost or fear losing power and want to build an alternative basis of support among youngsters and are ready to use intimidation and force. ${ }^{27}$

As religious and ethnic antagonisms are being discursively emphasized in the competition for resources and the quest for political power or elite rule (see Atieno-Odhiambo 2004), the young generation will be called upon and be used by power-holders as allies or vanguards in the realization of certain political goals, both peacefully and violently. That youths display agency in the process and can become autonomous forces to be reckoned with, dominating social movements and often setting an agenda of violent action, was evident in South Africa during apartheid, the West African wars, and in the conflict in Southern Sudan (see Jok this volume).

\footnotetext{
${ }^{27}$ Cf. the study by Makiko (2002), and the recent Human Rights Watch report (2004).
} 


\section{Youth and conflict}

The dynamics underlying the hardening ethno-regional and political identities mentioned above and their conversion into armed conflicts of alarming proportions are to be explained by, among others, the underlying dynamics of social exclusion and inequality as well as state crisis and economic decline reducing the cake available for division. Political antagonisms and conflict do not only exist on the discursive level but are also produced by demographic and social contradictions that can not be resolved within the conciliation mechanisms of the (post-colonial) African state or in accordance with the tenets of Africa's traditional political cultures.

The conflict between generations and/or age groups in many African countries is now a structural phenomenon in both the social and the political sense. As we saw above, the social problem that will not go away in many African neo-patrimonial countries is that of blocked social mobility. If only on the basis of demographics (the 'overproduction of youth'), finding employment and access to representative positions and political power is Utopian for mos youngsters, except for a happy few. The state sector is just too small and too poor a resource to redistribute and to provide for its many needy and ambitious citizens, and neither the formal economy nor the NGO sector - though expanding in many African countries - offer sufficient absorptive capacity. There is often an overproduction of highly educated graduates, at least in view of the very limited absorptive capacity of African economies. This phenomenon of blocked mobility is particularly acute in Africa (see for a discussion of specific examples: Toungara 1995, Abdullah 1997, Richards 1996, Peters \& Richards 1998), and will continue to form the background of the growth of opposition movements, criminal networks and armed revolts. Political insurgencies are often rooted in a combination of a structural lack of opportunities and generational antagonism, as exemplified in the leftist urban revolt of the Ethiopian People's Revolutionary Party in the 1970s and the ethno-regional rebellions of the Tigray People's Liberation Front (1975-1991) and the Oromo Liberation Front in Ethiopia, all of which emanated from the Marxist-leaning student protest movement against Emperor Haile Sellassie before 1974.

These examples show that resorting to conflict is one of the most frequent responses to a situation of stagnation and a lack of future prospects. There is also an element of revenge involved. The rebellious young generation, through looting and violence, consciously 'takes back' what they consider was monopolized by the older generation, often even from their leaders and kin relations. ${ }^{28}$ For armed insurgencies in countries where the state is not the allpowerful surveillance bureaucracy that exists in the developed West, there is still social and geographical space to develop a separate social domain (for example, experiments with revolutionary reforms in the countryside) and alternative routes to power.

In recent years, youth rebellions and/or generational tensions have developed a new social and political idiom, whereby the impact of new images and signs disseminated through Western or Asian mass media products (radio, TV, video, the Internet and other emerging electronic communication forms) are playing a growing role. Global genres and narratives are eagerly absorbed by youngsters, and local aspirations, desires and ideals are redefined by them (cf. Frederiksen 1999). Factors like ethnicity and cultural difference have been brought into play in recent years with references to ethnic 'oppression' or 'colonization', and with opposition parties, civil-society groups or rival presidential candidates being branded as 'tribalist', 'non-nationals', 'immigrants', 'narrow-nationalist' and 'chauvinist'. Youth militias, for instance in Nigeria, have emerged among specific ethnic groups (Yoruba, Igbo) and declare themselves, under the threat of intimidating violence, the custodians of public order or urban space. Thus, the discourse of autochthony and ethnic exclusionism has entered the politics of generational conflict in Africa.

\section{Youth and violence}

Young people are prominently involved in most of the existing armed conflicts and criminal networks on the African continent. The mere facts of demographic generational imbalance and socio-political tensions do not, however, explain why and how patterns of conflict and violence emerge among younger age groups, nor why they show such a remarkably uneven spread and intensity across the continent. For instance, in Tanzania, Botswana, Benin and Ghana we have not seen such cut-throat violence as in Sudan, Rwanda, Nigeria, Zimbabwe, Côte d'Ivoire or Somalia, and some movements, like the strongly disciplined and focused EPLF and TPLF in Eritrea/Ethiopia, have avoided humiliating and killing civilians.

A complex of political and sociological factors seem crucial here: a strong central state tradition, a society used to plurality of beliefs and ethnic identities i.e. that recognizes difference - and a pattern of values geared to restraint,

28 Bazenguissa (2003: 93) cites a young militia member in Congo-Brazzaville who, when asked why he was looting, put it exactly this way. 
cooperation and discursive conflict mediation appear to reduce the escalation of violent practices into brutal forms. It scems certain now that societies with traditional, culturally defined age-group systems or with age and generation grading are not necessarily more resilient to violent tensions (Abbink 2004, Simonse this volume). Cultural discourses of symbolic violence, for example in the context of initiation and secret society membership, can play a role, albeit indirectly (cf. Ellis 2003). The correlation between violence and religion is also unclear. Is it true that Islamic societies - marked by an ideology of 'unity of the believers', gender inequality, authoritarianism and weak educational structures are more prone to youth violence, especially against the background of the demographic 'youth bulge', as Samuel Huntington claimed on the basis of a statistic analysis (1998: 254-65), and, if so, why?

Another serious question is that of 'cultures of violence', more or less durable, socially rooted patterns of repeated violent practice or performance among certain groups that become integrated in a way of life and that thrive on intimidation and the abuse of power. Obviously, there is a contagious effect to state violence, often applied without measure and quite devastatingly, which may evoke similar practices in response. But still, violent performances by nonstate actors and those in alleged liberation or insurgent movements vary widely in nature and intensity. In a culture of violence they become ends in themselves, a source of arbitrary and gratuitous infliction of physical suffering and pain on others - often people from their own communities of origin. Examples are seen in insurgent movements in Sierra Leone, Liberia, Mozambique, Somalia and Sudan. Many such patterns of violence emerge in what are, or were, political insurgent movements with, at least initially, a number of political goals (for example, the RUF, NPFL, RENAMO), ${ }^{29}$ but also among criminal sub-cultures, of which perhaps the oldest forms are to be found in South Africa. ${ }^{30}$ It seems that practices long unknown elsewhere in Africa, such as burning opponents alive, gang rape, the sexual abuse of young children and public torture (mostly of fellow Blacks) were 'invented' in South Africa. The intensity of this violence is often explained by the specific conditions of political-economic repression and the traumatic ruptures in the socio-cultural life of Black South Africans under the colonial and apartheid system. These may have contributed to creating one of the most violently criminal, anomic societies in Africa, as we are still seeing years after the end of apartheid. But still, such acts do not explain this cruelty and humiliating violence and the evident joy that people get from them. The same issues surface time and again in the ongoing debate about the

\footnotetext{
${ }^{29}$ Cf. Mkandawire (2002).
}

${ }^{30}$ See, for instance, Mokwena (1991) and Glaser (2000). cruelties by RUF combatants in Sierra Leone against the civilian population. The cases of RENAMO, the Rwandan genocide, or, today (in 2004) the Janjawid militia violence in Darfur, Sudan, present similar problems. As Erik Bähre states in his interesting book Money and Violence (2003: 95), a politicaleconomic explanation of such violence simply falls short here. While it is easy to see the strategic advantage of using terror on civilians (to undermine the state), as well as of forcing child combatants to kill their family or members of their own community (to create extremely loyal fighters), ${ }^{31}$ violent practice is often pursued well beyond this, especially in the domain of mutilation, gender violence and torture. The element of enjoyment and the sense of impunity are disturbing and have perhaps to be explained in another way (see Baumeister 1996). When considering this matter, it is good to bear in mind comparable cases elsewhere in the world, not only the recent European wars, for example in Bosnia, but also organized crime, such as the intimidating and cruel punishments that the Italian mafia inflicted on opponents or detractors (cf. Gambetta 1993).

A good deal has been written on insurgent movements with an agenda of liberation and social reform but which cannot prevent a serious militarization of the society or group they claim to fight for (see Jok this volume). This phenomenon is quite common and is related to the emergence of a fighting caste that lives off violence, accepts military power as the only relevant authority and instils values of aggressive combat and self-assertion that flout ideals of sociality and respect. 'Disciplining' fighters is not only a matter of military leadership and internal cohesion but also of the strength of pre-existing values in the society from which a movement has emerged - religious leadership, gender relations, strength of the family, etc. - and of the way the insurgent movement has defined its relations with the civilian population. In unforeseen ways, the performance of violence undermines the social fabric and thus lays a heavy burden on post-conflict reconstruction.

The lasting impact of unsettling violence on both perpetrators and survivors is important because recent research has shown that the result is usually longterm trauma, dysfunctional family organization and precarious fertility behaviour. Images and practices of violence among both perpetrators and victims (especially when young) become part of a new habitus of violence - an internalized mental response pattern anchored in behavioural routines - and also a template in the collective memory of a society. They may thus resurface in new situations of crisis. The reconstitution of society after such phases of

31 Even apart from the general political-philosophical question of whether the use of such means is ever allowed and what end can possibly justify them. 

unsettling violence is therefore highly precarious, as Rwanda and Angola show,
and is never guaranteed.

\section{Youth and religion}

While the closing decades of the $20^{\text {th }}$ century may have shown the massive $21^{\text {st }}$ century of African youth in political and violent insurgent movements, the $21^{\text {st }}$ century will perhaps show a remarkable shift towards religious activity. Religion may be seen as an alternative circuit of meaning and dignity after the failure of political engagement (cf. Argenti 2002: 138). Recourse to religion combines the quest for meaning in an insecure world with the creation of a 'knowing' in belonging to a wider community, and presents an alternative way of knowing in the absence of access to proper public education and scientific knowledge. Religious groups can provide a new universe of values replacing or life in the family or ethnic context. There is a notable upsurge in religiou Christian Africa, with many youths becoming involved in Pentecostal and other Christian churches, with Islamic revivalism, and in some places with neotraditional indigenous movements (see Kanneworff 2004 , volume). This turn to the religious, hower sphere (see Ellis \& Ter Haar 2004) and ober, has a clear link with the political 4) and obviously does not preclude militancy and violence, as for instance the activities of several Islamist groups demonevidence of this Last's chapter in this volume also provides some historical

Interestingly, what these revivalist Christian and Islamic movements share is a disdain, even a repulsion, of 'traditional' African cultures and vare is leaders of these movements insist past and on a personal 'cleansing' on adherents effecting a total break with the the old culture and its 'harmful' of 'evil forces' seen as being associated with initiation, scarification, 'harmful' customs like bridewealth, widow inheritance, and epics. In itself this practices, and oral performances like praise songs socio-cultural ruptures that havical 'anti-heritage' movement accelerates the socio-cultural ruptures that have marked African societies and generational tury.

Chabal and Daloz, in their controversial book Africa Works (1999: 64), have
called the domain of the religious in been repeatedly criticized. supernatural shades into a reat there is no doubt that the sphere of the a readiness to succumb to mysticism, witchcraft and erroneous ideas about social causality, illness and morals. ${ }^{32}$ In conditions of

32 Cf. also the Comaroffs' (1999) existential insecurity, destitution and despair among the young, the willingness to believe tends to override questions of factual truth and rational effectiveness. This manner of belief has an enormous social and political impact because it tends to supplant the tangible realities of everyday life (cf. De Boeck 2000: 33). Youths are also involved in inventive frauds, trickster schemes and con games, such as the feymania originating in Cameroon in the $1990 \mathrm{~s} .{ }^{33}$ It would, however, be a mistake to see the resort to the imaginary or 'double' world of occult supernatural forces as only an African phenomenon.

In any event, religious thought and its global resurgence among the young have to be taken seriously. For our purposes, the point is that African youth are greatly attracted by the new religious movements and are joining (in large numbers) a discourse of morality and identity that holds out the promise of regeneration and collective power with transnational resonance. These movements will have a big impact on their members' self-image, their view of 'traditions', and on leadership ideals and roles. In addition, the economic dimension of these transnational religious movements is not to be underestimated. Not only do they receive funds (for example, remittances) from fellow members and related groups overseas, but also subsidies to propagate their faith and build new religious schools, ${ }^{34}$ churches and mosques in Africa. ${ }^{35}$ As the well-known examples of the Pentecostal churches in Africa or the Islamic Mouride brotherhood in Senegal illustrate, religious movements often function as frameworks of vigorous, joint economic action, promoting a new work ethic and creating new networks of opportunity.

steeped in supernatural imagery and violent representations and practices. De Boeck (2000) provides an interesting analysis of the disturbing phenomenon of "witchcraft children' in the Democratic Republic of the Congo.

${ }^{33}$ For an early study, see Malaquais (2001).

${ }^{34}$ However, they do not impart knowledge useful for improving young people's chances in the labour market.

35 Some Islamic countries have been the most active here. It is estimated that Saud Arabia alone has invested tens of billions of dollars in Africa in the past twenty years in 'overseas aid': for the building of mosques and religious schools, the distribution of copies of the Koran, and the training of Islamic teachers and missionaries. See political scientist Alex Alexiev's testimony before the US Senate, on http://judiciary.senate. gov/testimony.cfm?id $=827 \&$ wit_id $=2355$, citing the Saudi government newspaper $A$ in al-Yaqeen 


\section{Youth and the reconstitution of African societies}

There are high hopes in much of the literature about the potential and promise of youth in Africa and elsewhere. It is not the aim of this book to evaluate this normative issue but care should be taken not to see the young generation by definition as the agent of change. In negative as well as positive terms, the role of youth in the reconstitution of future African society is indeed obvious (Trudell 2002). They are both in the vanguard and at the same time vandals, depending on the conjunctures of economic opportunity, power structures and social space. Elements of hope are provided in the emergence of vibrant youth cultures, ${ }^{36}$ some with transnational connections such as the undiminished obsession with education, democratic activism, the commitment to family and cooperative values, and the wide response that anti-AIDS campaigns are finding among young people across Africa. The versatility of urban youth with new technologies and the media, ${ }^{37}$ and their commitment to open debate, democratic news media and social activism show that, when given the chance, youths can be constructive partners in the reconstitution of African societies. At present, however, these developments are only touching a small minority of African youth. The crucial factors that would allow youth to play a wider role are not determined by them: political stability and equity, an end to corruption and selective neo-patrimonialism, growing ecological problems and resource scarcity fuelled by unabated demographic imbalances, inequalities in the global system, ethnicized elite rule, and violent state repression. Through political and religious action, young people indeed are claiming agency and a greater stake for themselves. The force of arms has sometimes brought them to power, or has yielded huge spoils and benefits. Sometimes, the results of violence itself lead to a reconstitution of society. Religious action has increased collective identity and solidarity, economic advancement (for example, the Pentecostalists and their transnational connections), and political presence.

There remains, however, a fundamental ambiguity in the constitutive role of youth in society. One example is education. Youth in Africa attach great value to education: it is seen as the way out of poverty, and as a passport to employment and perhaps emigration to greener pastures outside the home country. It is a highly contested resource, and access to it can make or break a

\footnotetext{
36 See Fuglesang's (1994) interesting Kenya.

(n) Swahili youth culture in Lamu,

${ }^{37}$ A negative side of globalization is the rapid spread among urban youth in Africa of the worst kind of violent and pornographic video cassettes that are shown in illegal video houses. This phenomenon has already had a demonstrable effect on gender
perceptions and practices of sexual abuse.
}

person's future. But high-school drop-outs or even those with a diploma but no job are forced to sit idly at home with their parents on whom they become a burden, often pushed out onto the streets and drifting into street hawking, crime or a rebel movement. There is also a fundamental division between youngsters: a minority will make it, a majority not. And it often depends on luck. There is no automatic solidarity among youths in any country. For example, the exceedingly rich children of the business and political elite in Kenya have nothing in common with the youths from the slums who are members of Mungiki. Youth is thus variously incorporated or co-opted into society or its margins, showing that generations are vertically divided and thus pose no cohesive challenge to an established socio-political order.

While the role of youth as a 'mediating' social force in Africa - connecting tradition and modernity, the past and the present - is often somewhat exaggerated (e.g., De Boeck \& Honwana 2000: 11), young people can be seen as 'stakeholders' in the reconfiguration of society and the political project of a nation (cf. also McIntyre and Peters in this volume). Not only after conflict and civil war but also in the regular political process, governments have to deal with youths who claim rights and representation, and previously had reasons for joining an armed movement. In this respect, the present generation is more vocal and self-conscious than previous ones, perhaps because they are more aware of the power to contest and disrupt society. In more theoretical terms, youth agency has to be interpreted better as to its temporal and situated nature, referring back to the past and its meanings, as well as to the future seen through the prism of newly emerging ideals and desires.

\section{Relevance and theory}

The social relevance of studying youth in order to influence the development policies of donors, state, NGOs and self-organizations is growing. The Convention of the Rights of the Child was adopted by the United Nations in 1990 and is seen as the framework for global policy, although there is doubt about the ability of African governments to implement it. In 2003 the World Bank circulated a draft paper on 'Youth - Strategic Directions for the World Bank' in which it was acknowledged that neglecting youth in development policies is a costly mistake that needs to be redressed. The thought will no doubt find its way into future policy documents and country assistance programmes. It is indeed surprising that it has been absent from donor policy for so long, despite the usual rhetorical references. Social science and African studies have 
also rediscovered the subject and numerous studies are being made of street children, ${ }^{38}$ crime networks, youth movements, gender relations and conflict, the political agency of youths, and young (ex-) combatants (see Peters this volume). This renewed focus is welcome but is as yet still too weakly integrated in theory.

There is a need to develop sound theory for the study of youth and generational conflict, if only to be able to ask the right questions. A unified theoretical perspective is neither likely nor necessary but we think that the following key elements should be addressed in any attempt to develop more general explanations of the youth experience in Africa:

- the historical impact of the ruptures and changes in the political systems of Africa due to colonialism - that brought authoritarian structures, new elites, new borders, new ethnic identities - and the current world system enhancing global economic inequality is a major background factor.

- the post-colonial elites clinging to power and resources, thus blocking the emergent young generations. Thwarted socio-economic and political mobility creates instability and a tendency towards the use of force.

- the huge demographic expansion of the last forty years has put enormous strain on the adult generation and on the post-colonial state and its 'public delivery' structures (education, training, employment, health care, social services). The critical limits are most evident in the inadequate responses to the HIV/AIDS disaster.

- generational tensions in the wider sociological and cultural sense. While many of the traditional age and clan systems are in decline or are unsuccessful at offering solutions for problems engendered by modernity and state encroachment, the associated cultural representations ordering the relations between age groups and generations retain some importance. They are rooted in world-views, social memory, values and ritual performance, and are manifest in, for example, gender relations, deference to elders, initiatory symbolism, and the transformative meaning of (ritual) violence. The cognitive dimension of age and generational difference in African societies is underestimated.

- the crisis or decline of 'neo-patrimonial' state governance itself, with its zero-sum game politics, its exclusivist nature, its 'extraversion', its educational failure, and its repressive policies, is generating marginalization and destitution among social groups, including the young generation.

\footnotetext{
38 Marguerat (1992: 131, n. 6) notes that the phenomenon of street children is quite new, only emerging in Africa in the 1960s and 1970s.
}

Despair at survival or social advancement prepares youths for social experiments of all kinds, including deceit, crime and violence, also towards each other (cf. Lebeau 1999). Resource competition in conditions of scarcity, while essentially economic, resonates in group relations and politics, as ethnic and other cultural markers are used to differentiate people into opponents or allies.

- the potential of youth, because of their being young, marginal, not yet adult and established, to construct symbolic counter-discourse that challenges society in a moral and political sense and indicates alternatives. Increasingly, youth can find allies here in transnational global networks, in foreign NGOs, etc. and becomes the nexus and agent of change.

- the logic of violence and armed struggle, especially among youths, can attain a momentum of its own. Sub-cultures of criminal gangs and violent rebel movements claim social space by intimidation and destruction, 'resocialize' youngsters in a self-centred enclave culture, and rearrange power relations and the social order. Youths socialized in such 'cultures of violence' will remain an element of instability in any society trying to reconstitute itself in the post-conflict phase. Depending on the force of common values in the wider society, the presence of positive social incentives, and the legitimacy and efficacy of the political system upholding them, young people will not successfully 'return'.

- the gender dimension. The experience of female youths should not be ignored because of their lower 'nuisance value'.

These elements combine historical conditions with sociological and demographic mechanisms in a setting of cultural meanings to generate youth response. We do not plead for overly social-constructivist theories that relativize the concept of youth as a purely historical, situational category with little comparability across time or space (as Comaroff \& Comaroff seem to do, 2000: 91). On the contrary, it is more fruitful to explore, on the basis of a fairly universal psychological model of personal development (of youths into adults) and on that of the structural opposition, in virtually any society, of 'not-yet adults' vis-à-vis the preceding generation, the similarities and differences in collective representations of youth and in youth agency in conjunctures of crisis and change.

In the end, the three perspectives mentioned above - the agency, the interventionist and the analytic - must come together in a realist understanding of the experiences of youth in Africa. This allows us to recognize their diversity and to reconcile the dialectic of despair and crisis with that of survival and renewal. Research and writing on youth in Africa must also inform public debate and policy formation, and thus contribute to providing youth with the 

social space and agency that they need. It is hoped that the chapters in this book
do this.

\section{The chapters}

This book has three parts. In the first part, Historical Perspectives on Youth as Agents of Change, the chapters by Murray Last and Thomas Burgess present studies of youth action or agency at critical historical conjunctures. Both in northern Nigeria and in Zanzibar, movements fuelled by youth pathos and activist membership have brought about a significant change in existing and structures. What is notable in both cases is that Islam played a role, but unevenly, and not always as the dominant frame of reference. In the Sokoto jihad described by Last, Islam (or opposition to its dominant form) was the ideological idiom of rebellion referred to by the young to oust the older generation; in the case of the British conquest the older generation ruling the Caliphate saw defeat as a sign from God, but the young saw the new political structure as an opportunity. In the generation that planned the military coup of 1966 no religious reference was there, as youth simply grabbed the opportunity to assert themselves under the new conditions of national military power. Last's historical analysis has relevance for the understanding of contemporary volatile - developments in northern Nigeria.

In the Zanzibar revolution described by Burgess, an African-indigenous majority on the former slave-trader island, on the face of it, overturned IslamicArab hegemony in the name of social justice and an end to servitude. But the author, with reference to the historiographical debate, reinterprets the revolution as primarily a generational revolt, also within the population of Arab ancestry, connected to identity struggles and nationalist mobilization. Youth, in particular students, saw themselves as the vanguard that would put Zanzibar on the map as a socialist, developed nation, and for Burgess youth is to be considered as autonomously functional political identity.

In Part 2, on State, Crisis and the Mobilization of Youth, the emphasis is on contemporary dramas of youth as collective actors and as a socially marginal class. The chapters, all based on recent field research and set in the relevant theoretical debates, show that while young people are not in a strong social position, they are being urged to contest and challenge the state as a result of the in Africa is problems affecting them. In all the chapters, the crisis of the state in Africa is evident, but also that it is not yet a spent force.

Peter Kagwanja addresses the impact of the intriguing Mungiki movement, one of the more original and controversial social youth movements in Kenya, pleading for generational change in Kenyan politics and calling for national renewal on the basis of 'traditional' (Kikuyu) cultural values. This fascinating story shows how the force of 'culture' - be it selectively recovered and applied can be highly relevant in modern political processes in the post-colony. The Mungiki backs this up with a culture of force: violent actions, probably as a response to the widespread violence and displacement by regime-supported youth militias in the 1990s. A recent MA thesis by Kanneworff (2004), based on inside fieldwork with the leaders and regular members of Mungiki, also considers this issue. The position of Mungiki in the democratic process in Kenya indeed seemed a riddle, with the movement apparently preferring generational change (by rallying behind the young Uhuru Kenyatta, a member of the KANU ruling party of the hated President Moi) to the election of Mwai Kibaki, the senior candidate of the democratic opposition, because he was an old man. But the Mungiki leadership was also being pragmatic: it sought any opportunity to gain a share of the power and deliver on promises to its disadvantaged young adherents. When Kibaki and his party won the 2002 elections, a violent self-assertion of Mungiki, such as in January 2003, was almost inevitable.

Karel Arnaut analyses in detail the backgrounds of the recent conflict in Côte d'Ivoire, a country where nobody really expected such an explosion of violence and disunity as has been seen in the past few years. But such a statement perhaps underestimates the problems of the patriarchal one-party state that Côte d'Ivoire was under Houphouët-Boigny. Ivoirian youths spearheaded the upheaval and, as in so many cases in Africa, the seedbed of rebellion was a national student movement, the FESCI, founded in 1990. The two new youth movements of recent years, the Young Patriots and the New Forces, claiming primacy because they were the young generation opposed to the one in power, seem to have set much of the political agenda in the country, this time inspired by an autochthony debate about who 'belongs' to the nation and who does not.

The chapter by Piet Konings is a revealing and authoritative study of student politics in Cameroon, highlighting the struggle of a doubly marginalized group, the Anglophone students, on behalf of their region. The aggravating economic and political crisis of the country created a treacherous arena for heightened power struggles and exclusionism by the reigning elite, pursued by all available means. Konings speaks about 'protracted warfare' between state and students, with the authorities unable to see or admit the rights of the young generation, and certainly not when coupled to an Anglophone agenda demanding more representation or autonomy. He also demonstrates the deep divisions existing within the student body due to vertical loyalties of an ethno-regional and political nature, and, thus, underlines a point made above that the young generation, and particularly students vis-à-vis the state, have no natural cohesion and commonality of interest. 
Jok Madut Jok's important chapter on Dinka communities involved in the long war in Southern Sudan painfully illustrates the pernicious effects of long term violence on the society from which the combatants, members of the SPLA and fighting for the rights of the Southerners, emerged. The war created a mindset of military supremacy that was very attractive for youngsters who, by enlisting, could escape idleness and circumvent laborious socio-cultural practices. But it negated traditional cultural values on gender relations and respect for women, children or elders, procreation and legitimate authority relations that were bound to the moral universe of the society and not to those of the wider world, thus evoking a internal social crisis in Dinka society of enormous magnitude. ${ }^{39} \mathrm{Jok}$, interestingly, also highlights the importance that religious conversion can have for intergenerational tensions due to the distance created between young Christian converts and their non-converted parents. This is a general problem seen in contexts of conversion to certain forms of the Islamic and Christian faiths (for example, Pentecostalism).

Sara Dorman's analysis of the changing role of youth in Eritrea is one of the first of such studies and of interest because of the rapidly changing conceptions of politics and nation-building in this country, only independent (de facto) since 1991. Eritrea fought in a war against Ethiopia that was carried out by a young generation of students from the early 1970s onwards, who came of age during the fighting. 'Youth' was always a prime metaphor for the future and the new political order and in the early years there was a remarkable sense of purpose and unity. Eritrea set up one of the most massive youth mobilization efforts ever seen in Africa, with compulsory national service for youth (in this case defined as all those between the ages of 18 and 40), military training, and high-school students spending their last year in classes organized by the Ministry of Defence, but also participating in social projects. Politicians' speeches are replete with references to the obligations of the young generation to the 'martyrs' who secured independence. Dorman shows that, in the stifling political atmosphere in the country, slowly and inevitably cracks emerged in the projected picture of unity and solidarity between the generations. In the eyes of the governing circles, the young generation has no agency and no autonomy but must continue to follow the precepts of nation-building as defined by the
leaders.

In the last part, entitled Interventions: Dealing with Youth in Crisis, the spotlight is on crisis situations and their aftermath, notably young combatants and their problematic 'return' to a more or less normal, non-war situation. Yves Marguerat's impressive chapter is on the expanding problem of street children

\footnotetext{
${ }^{39}$ Similar developments were seen in Nuer society; see Hutchinson (1996).
}

in urban Africa, and points to the dangers of an almost self-reproducing "subculture' that is emerging. His case study of Lomé children, sensitive and insightful, is the result of long years of work with these children, and continues a series of remarkable studies that made the author a world authority on the subject. ${ }^{40}$

Simon Simonse describes in perceptive detail a, by now, quite general situation among pastoral people in Africa: the breakdown of social order as exemplified by the age or generation system, and the alarming spread and use of automatic rifles, impacting in unexpected and unintended ways on people's social organization, notably gender relations. In Karamoja, women, as victims of violence (including sexual abuse), are also on the receiving end when faced with the violent deaths of brothers, husbands and children, and become the victims of overburdening rules such as widow inheritance. Women are coming to question not only the massive violence but also their own culture. Many pastoral societies are thus becoming internal war zones and are showing deep divisions that are not going to be solved in the immediate future. As a staff member of an influential Dutch NGO, Simonse is actively working on projects in Uganda (and elsewhere in Africa) trying to change this situation.

McIntyre and Peters address similar issues related to the rehabilitation or resocialization of young ex-combatants in a post-conflict society. The issue is highly relevant, not only because of the large numbers of youngsters involved and still more to come when, for example, some form of normality returns to Sudan, northern Uganda and Somalia - but also because of the difficulties in reconstituting society in conditions of economic scarcity, disagreement about values and a plurality of political models for the future.

McIntyre proposes properly recognizing the role of young combatants as stakeholders, both in a period of fighting - they were not only simple naïve recruits manipulated by others but also took decisions to become involved - as well as thereafter, in the phase of return to or reconstruction of a civil society, where a sensitive attitude towards their past experience and an understanding of their aspirations are required. The issue takes on special importance in view of the international concern, if not obsession, with child soldiers and their lot.

Peters's chapter is a revealing account about the problematic articulation of wartime values acquired by youths in violent armed movements with those of the society into which they are expected to reintegrate (although some young ex-combatant will have spent their entire lives in the movement). With convincing empirical case material the author shows that those wartime values

${ }_{40}$ See Y. Marguerat \& D. Poitou (eds), À l'Ecoute des Enfants de la Rue, Parıs: Fayard (2003) 
have reinforced generational, or indeed general, opposition $v i s-\grave{a}$-vis the society of origin of the combatants, precluding an easy 'return'. The author also highlights the underestimated differences that existed within the RUF and other fighting forces in Sierra Leone in terms of the precarious internal organization of factions. Peters's conclusions about the relevance of knowing the motives and backgrounds of ex-combatants in order to make reintegration packages more effective can only be supported. Lastly, while not the focus of his chapter Peters's account points to the relevance of a wider debate on values in African societies (for example, regarding child-raising, gender roles, the role of the supernatural, kinship, trust, work, relations of authority) and their possible connection with socio-economic development. ${ }^{41}$

\section{Acknowledgements}

The editors wish to express their deepest gratitude to Ann Reeves for her valuable editorial assistance. Our sincere thanks also go to Marieke van Winden for her efficient logistical help in organizing the 2003 African Studies Centre conference $^{42}$ that provided the basis of this book, to Mieke Zwart for her work on the layout that went beyond the call of duty, and to Nel de Vink for the maps. Finally, we are particularly indebted to the Netherlands Ministry of Foreign Affairs for generously supporting the conference and providing the funds that enabled a number of African colleagues to travel to Leiden.

\section{References}

Abbink, J. 1994, "Changing Patterns of "Ethnic" Violence: Peasant-Pastoralist Confrontation in Southern Ethiopia and its Implications for a Theory of Violence', Sociologus, 44 (1): 66-78.

Abbink, J. 2003, 'Ritual and Political Forms of Violent Practice', in T. Young (ed.), Readings in African Politics, Oxford: James Currey, pp. 80-89.

Abbink, J. 2004, 'Culture Slipping Away: Violence, Social Tension and Personal Drama in Suri Society, Southern Ethiopia', in A. Rao, M. Böck \& M. Bollig (eds), The Practice of War, London \& Oxford: Berghahn, forthcoming.

Abdullah, I. 1997, 'Lumpen Youth Culture and Political Violence: Sierra Leoneans Debate the RUF and the Civil War', Africa Development, 22 (3/4): 171-215.

${ }^{41}$ For a controversial but thought-provoking book on the subject, see Harrison \& Huntington (2000). Two of its chapters are about Africa. Political correctness codes in academia seem to have inhibited a thorough debate on this Weberian topic of the role of values in development in Africa. 42 The two-day conference was organized by the ASC's 'Culture, Power and Inequality
in Africa' theme group and held in Leiden in April 2003 .
Abélès, M. \& C. Collard (eds) 1985, Age, Pouvour et Société en Afrique Noire, Montréal/Paris: Presses de l'Université de Montréal/Karthala.

Aguilar, M.I. 1998, 'Reinventing Gada: Generational Knowledge in Boorana', in M.L. Aguilar (ed.), The Politics of Age and Gerontocracy in Africa, Trenton, NJ \& Asmara: Africa World Press, pp. 257-80.

Argenti, N. 2002, 'Youth in Africa: A Major Resource for Change', in A. de Waal \& N. Argenti (eds), Young Africa: Realising the Rights of Children and Youth, Trenton, NJ/Asmara: Africa World Press, pp. 123-34.

Atieno-Odhiambo, E.S. 2004, 'Ethnic Cleansing and Civil Society in Kenya 19691992', Journal of Contemporary African Studies, 22 (1): 29-42.

Bähre, E. 2002, Money and Violence. Financial Mutuals among the Xhosa in Cape Town, South Africa, University of Amsterdam, $\mathrm{PhD}$ thesis.

Balsvik, R.R. 1985, Haile Selassie's Students: the Intellectual and Social Background to a Revolution, 1952-1977, East Lansing: Michigan State University.

Bassi, M. 1996, 'Power's Ambiguity, or the Political Significance of Gada', in P.T.W. Baxter, J. Hultin \& A. Triulzi (eds), Being and Becoming Oromo, Lawrenceville, NJ: Red Sea Press, pp. 150-61.

Baumeister, R.F. 1996, Evil. Inside Human Cruelty and Violence, New York: W.H. Freeman.

Bazenguissa-Ganga, R. 2003, 'The Spread of Political Violence in Congo-Brazzaville', in T. Young (ed.), Readings in African Politics, Oxford: James Currey, pp. 89-96.

Black, R., S.S. Morris \& J. Bryce 2003, 'Where and Why are 10 Million Children Dying Every Year?', The Lancet, 361, 2226-34.

Chabal, P. \& J-P. Daloz 1999, Africa Works. Disorder as Political Instrument, Oxford/Bloomington, Indianapolis: James Currey/Indiana University Press.

Clapham, C. (ed.) 1998, African Guerrillas, Oxford/Bloomington, Indianapolis: James Currey/Indiana University Press.

Comaroff, J. \& J. Comaroff 1999, 'Occult Economies and the Violence of Abstraction: Notes from the South African Postcolony', American Ethnologist, 26 (2): 279-303.

Comaroff, J. \& J. Comaroff 2000, 'Réflexions sur la Jeunesse. Du Passé à la Postcolonie', Politique Africaine, 80, 90-110.

Cruise O'Brien, D.B. 1996, 'A Lost Generation?: Youth Identity and State Decay in West Africa', in R. Werbner \& T. Ranger (eds), Postcolonial Identities in Africa, London: Zed Books, pp. 55-74.

D'Almeida-Topor, H., "Jeune", "Jeunes", "Jeunesse": Réflexions autour d'une Terminologie', in H. d'Almeida-Topor, C. Coquéry-Vidrovich, O. Goerg \& F. Guitart (eds) 1992, Les Jeunes en Afrique, Paris: Éditions l'Harmattan, vol.1, pp. 14-16.

D'Almeida-Topor, H., C. Coquéry-Vidrovich, O. Goerg \& F. Guitart (eds) 1992, Les Jeunes en Afrique, Paris: Éditions l'Harmattan, 2 volumes.

Dane, B.O. \& C. Levine (eds) 1994, AIDS and the New Orphans: Coping with Death, Boston: Auburn House.

De Boeck, F. 2000, "Le "Deuxième Monde" et les "Enfants-Sorciers" en République Démocratique du Congo', Politique Africaine, 80, 32-57.

De Boeck, F. \& A. Honwana 2000, 'Faire et Défaire la Société: Enfants, Jeunes et Politique en Afrique', Politique Africaine, 80, 5-11. 
De Waal, A. \& N. Argentı (eds) 2002, Young Africa Reallsing the Rights of Children and Youth. Trenton, NJ \& Asmara' Africa World Press.

Dyson-Hudson, N. 1966, Karimojong Polttics, Oxford: Clarendon Press.

Ellis, S. 2003, 'Violence and History: A Response to Thandika Mkandawire', Journol of Modern African Studies, 41 (3): 457-475.

Ells, S. \& G. ter Haar 2004, Worlds of Power. Religious Thought and Political Practice in Africa, London: C. Hurst \& Co.

Falola, T. (ed.) 2004, Teen Life in Africa, Westport \& London: Greenwood Press.

Fratkin, E. 1998, Ariaal Pastoralists of Kenya: Surviving Drought and Development Africa's Arid Lands, Boston: Allyn \& Bacon.

Frederiksen, B.F. 1999, "We Need That Life". Global Narratives and Local Aspirations among Youth in a Nairobi Slum', in N.N. Sørensen (ed.), Narrating Mobility, Boundaries and Belonging, Copenhagen: Centre for Development Research, Working Paper 99.7, pp. 49-64.

Fuglesang, M. 1994, Veils and Videos. Female Youth Culture on the Kenyan Coast Stockholm University, $\mathrm{PhD}$ thesis.

Gambetta, D. 1993, The Sicilian Mafia: The Business of Private Protection, Cambridge: Harvard University Press.

Glaser, C. 2000, Bo-tsotst The Youth Gangs of Soweto 1935-1976, Portsmouth, NH: Heinemann.

Gosselin, C. 2000, 'Feminism, Anthropology and the Politics of Excision in Mall: Global and Local Debates in a Postcolonial World', Anthropologica, 42 (1): 43-60.

Habtamu Wondimu (ed.) 1996, Research Papers on the Situaton of Children and Adolescents in Ethiopia, Addis Ababa: Addis Ababa University Printing Press. Harrison, L.E. \& S.P. Huntington 2000, Culture Matters: How Values Shape Human
Progress, New York: Basic Books.

Hunnant, J. 1978, 'The Guji: Gada as a Ritual System', in P.T.W. Baxter \& U. Almagor (eds), Age, Generation and Time. Features of East African Age Group Systems, London: C. Hurst \& Co., pp. 207-43.

Human Rights Watch 2004, "Political Shari'a"? Human Rights and Islamic Law in Northern Nigeria. New York: HRW.

Huntington, S.P. 1998, The Clash of Civilizations and the Remaking of World Order, London \& New York: Touchstone Books.

Hutchinson, S.E. 1996, Nuer Dilemmas. Coping with War, Money and the State, Berkeley, Los Angeles \& London: University of California Press.

Kanneworff, A.B. 2004, "These Dread-Locked Gangstornia Press. Kenia: Van Neo-Etnisch Protest naar Politieke Participatie', Vrije Universiteit, Amsterdam, MA thesis.

Kessel, I. van 2000, 'Beyond Our Wildest Dreams': The United Democratic Front and the Transformation of South Africa, Charlottesille United Democratic Front and Virginia.

Lebeau, Y. 1999, 'Permissivité et Violence sur les Campus Nigérians', Politique Africaine, 76: 173-80

Legesse, A. 1989, 'Adaptation, Drought and Development: Boran and Gabbra Pastoralists of Northern Kenya', in R. Huss-Ashmore \& S.H. Katz (eds), African Food Systems in Crisis, New York: Gordon \& Breach, pp. 261-79.
Machel, G. 1996, Impact of Armed Conflict on Children, New York: United Nations. (also avallable online at: http.//www.unicef.org/graca/a51-306_en.pdf)

Makiko, T. 2002, 'Religion and Politics in Nigeria: The Real Causes of the Sharia Conflict in 2000', Journal of Asian and African Studies, 64, 217-236.

Malaquais, D. 2001, Anatomie d'une Arnaque: Feymen et Feymania au Cameroun. Les Études du CERI 77

Marguerat, Y. 1992, 'Les Smallvi Ne Sont Pas des Gbevouvi: Eléments pour une Histoire de la Marginalité Juvénile à Lomé', in H. d'Almeida-Topor, C. CoquéryVidrovich, O. Goerg \& F. Guitart (eds) 1992, Les Jeunes en Afrique, Paris: Éditions l'Harmattan, vol. 1, pp. 130-54.

McIntyre, A., E.K. Aning \& P.N.I. Ado 2002, 'Politics, War and Youth Culture in Sierra Leone: An Alternative Interpretation', African Security Review, 11 (3): 7-15.

Mkandawire, T. 2002, 'The Terrible Toll of Post-Colonial Rebel Movements in Africa: Towards an Explanation of the Violence Against the Peasantry', Journal of Modern African Studies, 40 (2): 181-215.

Mokwena, S. 1991, 'The Era of the Jackrollers: Contextualising the Rise of Youth Gangs in Soweto', Braamfontein: Centre for the Study of Violence and Reconciliation.

Ndlovu-Gatsheni, S.J. 2003, 'Dynamics of the Zimbabwe Crisis in the $21^{\text {st }}$ Century', African Journal of Conflict Resolution, 3 (1): 99-134.

Péatrik, A-M. 1993, 'Age, Génération et Temps Chez les Meru, Tigania-Igembe du Kenya', Africa, 63 (2): 241-60.

Péatrik, A-M. 2003, 'Arrangements Générationnels: Le Cas Inattendu des Gusii (Kenya)', L'Homme, 167-168: 209-34.

Peters, K. \& P. Richards 1998, "Why We Fight": Voices of Youth Combatants in Sierra Leone', Africa, 68 (2): 183-210.

Richards, P. 1996, Fighting for the Rain Forest: War, Youth and Resources in Sierra Leone, London/Portsmouth, NH: James Currey/Heinemann.

Richter, L., A. Dawes \& C. Higson-Smith (eds) 2004, Sexual Abuse of Young Children in Southern Africa, Cape Town: Human Sciences Research Counc1l Publishers.

Rossi, A. (ed.) 2003, Trafficking in Human Beings, especially Women and Children, in Africa. Florence: UNICEF Innnocenti Research Centre.

Sharp, L.A. 2002, The Sacrificed Generation. Youth, History and the Colonized Mind in Madagascar, Berkeley, Los Angeles \& London: University of Calıfornia Press.

Schatz, S.P. 2002, 'Structural Adjustment', in G.C. Bond \& N.C. Gibson (eds), Contested Terrains and Constructed Categorles: Contemporary Africa in Focus, Boulder: Westview Press, pp. 87-104.

Smith, S. 2003. Négrologie. Pourquoi l'Afrique Meurt, Paris: Calmann-Lévy.

Stewart, F.H. 1977, Fundamentals of Age-Group Systems, New York: Academic Press. Stohl, R.J. 2002, 'Under the Gun: Children and Small Arms', African Security Review, $11(3): 17-25$.

Tornay, S. 2001, Les Fusils Jaunes. Générations et Politique en Pays Nyangatom (Éthiopie), Nanterre: Société d'Ethnologie.

Toungara, J-M. 1995, 'Generational Tensions in the Parti Démocratique de Côte d'Ivoire', African Studies Review, 38 (2): 11-38. 
Trudell, B. 2002, 'Introduction: Vulnerability and Opportunity among Africa's Youth', in B. Trudell et al (eds) 2002, Africa's Young Majority, Edinburgh: Centre of African Studies, Edinburgh University, pp. 1-15.

Trudell, B. et al. (eds) 2002, Africa's Young Majority, Edinburgh: Centre of African Studies, Edinburgh University.

Turton, D. 1995, 'History, Age and the Anthropologists', in G. Ausenda (ed.), After Empire. Towards an Ethnology of Europe's New Barbarians, London/San Marino: Boydell Press/Center for Interdisciplinary Research on Social Stress, pp. 95-112.

Walle, N. van de, N. Ball \& V. Ramachandran (eds) 2003, Beyond Structural Adjustment. The Institutional Context of African Development, New York/Houndmills Palgrave/Macmillan.

Wilson, M. \& M. Daly 1993, 'Lethal Confrontational Violence among Young Men', in N.J. Bell \& R.W. Bell (eds), Adolescent Risk Taking, Newbury Park: Sage, pp. 84 106.

Young, J.W. 1997, Peasant Revolution in Ethiopia: The Tigray People's Liberation Front, 1975-1991 Cambridge: Cambridge University Press.

\section{PART I: \\ Historical perspectives on youth as agents of change}

